УДК 625.12

\title{
ПЕРЕБУДОВА ВОДОПРОПУСКНИХ ТРУБ ПІД ЧАС РЕКОНСТРУКЦЇ̈ ЗАЛІЗНИЦЬ
}

\author{
С.А. Губаренко
}

\section{ПЕРЕСТРОЙКА ВОДОПРОПУСКНЫХ ТРУБ ПРИ РЕКОНСТРУКЦИИ ЖЕЛЕЗНЫХ ДОРОГ}

\author{
С.А. Губаренко
}

\section{CULVERT RECONSTRUCTION DURING THE RAILWAY RECONSTRUCTION}

\section{S.A. Gubarenko}

Наведено два варіанти технологічних схем реконструкиіі водопропускних труб, визначено галузі їх застосування. Запропоновано технологічну послідовність робіт 3 перебудови труб за обома варіантами.

Ключові слова: реконструкиія залізниць, перебудова водопропускних труб, подовження водопропускних труб, технологія робіт.

Приведень два варианта технологических схем реконструкции водопропускних труб, определены области их применения. Предложена технологическая последовательность работ по перестройке трубы по обоим вариантам.

Ключевые слова: реконструкция железных дорог, перестройка водопропускных труб, удлинение водопропускных труб, технология работ.

Two variants of culvert reconstruction technological schemes are given, scopes of their application are determined. Technological work order of culverts reconstruction for both variants is offered.

Keywords: reconstruction of railways restructuring culverts, extension of culverts, the technology works.

У процесі реконструкції залізниці в разі збільшення ширини земляного полотна, а також при підвищенні насипу або уположенні укосів виникає необхідність збільшення довжини водопропускних труб. При цьому можливі два варіанти:

a) повна перебудова водопропускної труби, яку здійснюють у тих випадках, коли діагностика i прогнозування стану труби показують, що існуюча труба не зможе нормально працювати до наступної реконструкції залізниці; б) подовження водопропускної труби без перебудови існуючої частини. Здійснюють, якщо стан існуючої труби дає змогу очікувати іiі нормального функціонування до нової реконструкції залізниці при відповідному утриманні й ремонті.

Роботи $з$ перебудови або подовження труб бажано проводити в суху пору року або в зимовий період, щоб уникнути впливу потоку води, що протікає через трубу, на хід робіт. Роботи повинні бути організовані таким чином, щоб не 
перешкоджати руху поїздів або знизити можливі перешкоди до мінімального ступеня.

Повна перебудова труби включає в себе такі основні операції, багато 3 яких аналогічні будівництву нової водопропускної труби. До початку робіт здійснюють заходи щодо обмеження швидкості руху на ділянці зі встановленням відповідних знаків. Потім виконують розбирання верхньої будови колії, вирізання відповідної частини баласту i земляного полотна та їх вивіз iз застосуванням бульдозерів, одноківшових (фронтальних) навантажувачів та автомобілів-самоскидів. Після вирізання земляного полотна відривають котлован для звільнення старої труби від грунту до рівня підошви фундаменту (основи) із застосуванням екскаватора 3 робочим обладнанням зворотної лопати. Для безпеки і зручності робіт при розбиранні старої і монтажі нової труби котлован по підошві повинен бути ширше основи старої труби 3 одного боку на 3 м (для проходження машин), а 3 другого боку на 1 м (для руху робітників).

$$
\text { Укіс котловану повинен }
$$
забезпечувати безпеку робіт (зазвичай не крутіше 1:1). Якщо через трубу в процесі їі перебудови можливе проходження води, котлован розширюють i в ньому влаштовують тимчасове обвідне русло, ширина і глибина якого розраховуються.

$\begin{array}{ccc}\text { При } & \text { відповідному } & \text { техніко- } \\ \text { економічному } & \text { обгрунтуванні } & \text { можливе }\end{array}$
влаштування котловану 3 кріпленням укосів, що дає змогу збільшувати їx крутість, зменшуючи об'єм земляних робіт. Після цього розбирають трубу із застосуванням пневматичних або електричних відбійних молотків (відповідно до пересувних компресорів або електростанцій), автокранів, бульдозерів, автомобілів для транспортування до місця складування блоків розібраної труби. Якщо лекальні блоки й основа труби (зазвичай гравійно-піщаний або щебеневий шар) не мають неприпустимих дефектів, вони можуть бути збережені. За наявності руйнувань (тріщини, значні обломи) лекальні блоки або частину 3 них видаляють. Матеріал основи зсувають за межі котловану бульдозером. Можливе використання матеріалу основи для зміцнення тимчасового відвідного русла.

Потім здійснюють планування й ущільнення дна котловану (при видаленні лекальних блоків і основи) за допомогою бульдозера i віброкотків або (раціональніше) віброплит. Рівень поверхні дна повинен відповідати вимогам проекту перебудови труби. При необхідності при плануванні проводять досипання котловану грунтом того ж виду, що й місцевий грунт. Улаштовують пандус для в'їзду автомобілів з ухилом до 100 \%. Пандус споруджують 3 верхової частини труби. На спланованому і ущільненому дні котловану влаштовують основу 3 піщано-гравійної або щебеневої суміші, якщо така основа передбачена проектом. Піщано-гравійну або щебеневу суміш вивозять автомобілямисамоскидами, планують бульдозером (можливо вручну) i ущільнюють самохідними або ручними віброкотками. За сприятливих грунтово-кліматичних умов (піщані грунти, глибина промерзання менше $0,5 \mathrm{~m}$ ) основу 3 піщано-гравійної суміші можна не влаштовувати (це має бути передбачено проектом).

Потім проводять розподіл цементного розчину, підвезеного автомобілямисамоскидами або виготовленого на місці, $\mathrm{i}$ установлення (монтаж) портальних стінок, блоків, відкрилків і лекальних блоків. Цементний розчин зазвичай розподіляють вручну шаром 10-15 cм, а портальні стінки, блоки, відкрилки i лекальні блоки монтують автокраном або краном на гусеничному ходу. При укладанні на лекальні блоки ланки труб повторюють профіль, за яким укладені лекальні блоки. Позначки лекальних блоків повинні бути перевірені нівеліром. Рівень лекальних 
блоків регулюють товщиною шару цементного розчину.

Монтаж ланок труби проводиться із застосуванням автокрана або крана на гусеничному ходу. Потім виконується замонолічування швів між блоками портальних стінок і відкрилків, закладення та гідроізоляція швів ланок.

Шви портальних стінок і відкрилки конопатять i заповнюють цементним розчином, який ущільнюють металевим шуруванням. Гідроізоляція швів ланок здійснюється двома шарами бітумінізованої тканини і трьома шарами азбестобітумної мастики.

При будівництві двох- i триочкових труб пазухи між цими трубами заповнюють цементобетоном, що доставляється автомобілями-самоскидами, автобетонозмішувачами або виготовляється на місці. Цементобетон до пазух подають у цебрах за допомогою автомобільного або гусеничного крана або через бункер, оснащений металевим рукавом. Ущільнення цементобетону в пазухах здійснюють різними глибинними вібраторами (вібробулава, віброштик та ін.).

Гідроізоляція труби може здійснюватися з улаштуванням обклеювальної або обмазувальної гідроізоляції. У першому випадку трубу покривають за допомогою ручного розподільника бітумною мастикою, доставленою автогудронатором. Потім наклеюють рулонний матеріал (зазвичай руберойд), знову обмазують бітумною мастикою і наклеюють рулонний матеріал. Обмазувальну гідроізоляцію влаштовують шляхом обмазування зовнішньої поверхні труби бітумним лаком 3 подальшим нанесенням двох шарів бітумної мастики.

Засипання котловану 3 пошаровим ущільненням виконують бульдозером, починаючи 3 бічних пазух, де грунт ущільнюють механічними трамбівками. Так само ущільнюють грунт і над трубою до загальної товщини відсипки 0,5 м в ущільненому стані. Товщина кожного шару, що ущільнюється, в пазухах і над трубою при використанні механічних трамбівок повинна бути 0,10-0,12 м. Вище товщини 0,5 м до верху котловану ущільнення виконують самохідними віброкотками. Товщина шару, який ущільнюється, при цьому 0,15 м. Грунт повинен мати оптимальну вологість. Засипання подовженої частини труби проводять одночасно 3 розширенням земляного полотна. Після цього проводять розчищення русел із зміцненням бетонною плиткою i зміцненням укосів біля оголовків, а також будівництво водобійного колодязя, якщо він передбачений проектом реконструкції труби.

Повна перебудова прямокутної труби включає в себе операції, аналогічні розглянутим раніше, за винятком монтажу лекальних блоків, замість яких зазвичай роблять монолітний бетонний фундамент.

Великі прямокутні залізобетонні труби часто бетонують на місці. При цьому на підготовлену основу встановлюють опалубку, монтують і зварюють арматурний каркас, роблять бетонування із застосуванням крана і цебра. Ущільнення виконують зовнішніми вібраторами через опалубку, а також при можливості використовують глибинні вібратори.

Подовження водопропускної труби для зменшення обсягу робіт доцільно робити з боку вихідного оголовка. Тому в даному місці передбачають однобічне розширення земляного полотна. У процесі подовження труби виконують такі основні операції. У разі постійного протікання води через трубу влаштовують 3 нижнього боку тимчасове відвідне русло із застосуванням екскаватора зі зворотною лопатою i видаляють матеріали укріплення лотка i укосів. Видалення грунту укосу, що примикає до оголовка, виконують із застосуванням екскаватора зі зворотною лопатою. Розбирання оголовка труби, включаючи відкрилки і портальну стінку, проводиться із застосуванням пневматичних або електричних відбійних 
молотків і автомобільного крана або крана на гусеничному ходу, що розташовуються зазвичай на насипі.

Розроблення котловану для основи $\mathrm{i}$ фундаменту подовженої труби виконується iз застосуванням екскаватора зі зворотною лопатою. Якщо у котлован надходить вода, необхідно забезпечити іiі відкачування i спуск по ухилу. При цьому можливе влаштування тимчасового зливного лотка. Планування й ущільнення дна котловану проводяться аналогічно викладеному для повної перебудови труби. Те ж стосується і влаштування основи 3 піщано-гравійної або щебеневої суміші, розподілу цементного розчину, монтажу портальних стінок, блоків відкрилків, лекальних блоків частини труби, яка подовжується. Потім аналогічно повній перебудові труби проводять монтаж ланок труби, яка подовжується, між блоками портальної стінки і відкрилками, замонолічення швів, закладення i гідроізоляцію швів ланок, заповнення цементобетоном пазух при двох- або триочкових трубах, гідроізоляцію труби. Роботи завершуються улаштуванням лотка біля відвідного оголовка, будівництвом водобійного колодязя, якщо він передбачений проектом реконструкції труби, і засипанням грунтом подовженої частини труби, яке проводять одночасно 3 розширенням земляного полотна.

\section{Список використаних джерел}

1. Устройство, реконструкция и капитальный ремонт водопропускних труб. СТО НОСТРОЙ ХXX-20 [Текст] / Союздорстрой. - М., 2012. - 79 с.

2. Кириллов, В.С. Эксплуатация и реконструкция мостов и труб на автомобильных дорогах [Текст] / В.С. Кириллов. - М.: Транспорт, 1971. - 196 с.

Рецензент д-р техн. наук, професор О.М. Даренський

Губаренко Сергій Анатолійович, слухач ІППК.

Gubarenko S.A. 